\title{
Pollution assessment of Euphrates River in three governances of Iraq
}

\author{
Alaa Al-Fatlawi ${ }^{1 *}$, Mohammed Al-Jassani ${ }^{2}$, and Jawad Al-Rifaie ${ }^{3}$ \\ ${ }^{1}$ Engineering College, Babylon University, Hilla, Iraq \\ ${ }^{2}$ Al-Alamain Institute for Higher Education, Hilla, Iraq \\ ${ }^{3}$ Al-Furat Al-Awsat University, Karbala, Iraq
}

\begin{abstract}
This study was concerned with assessment the water quality of Euphrates River in the middle of Iraq. Water quality assessment is the overall process of evaluation of the physical, chemical and biological nature of the water. Water pollution for Euphrates River in Middle of Iraq (Babylon, Al-Najaf, and AlDiwaniya governorates) occurs in both rural and urban areas. In rural areas, drinking water from natural sources such as rivers and streams is usually polluted by organic substances from upstream users who use water for agricultural activities. To protect the water resources from pollution and deterioration which caused by natural pollutants or human activities, an environmental database was constructed and applied. A Visual Basic (version 6.0) Software program was constructed to evaluate the pollutant concentrations using regression models obtained by Data Fit Software program (version 8.0) to make the monitoring system. The result of the program is verified with data of year 2008 which is not included in regression model. This verification shows a good agreement with coefficient of determination ranged between "0.914 to 0.994"To assess water body for compliance with standards that have been set to define requirements for various functions and uses, the water body concerned, were compared with the Iraqi, and WHO standards for domestic and irrigation purposes, for determining whether water quality at sampling sites exceeds water quality standards. A comparison shows that these parameters in some stations are within the Iraqi and WHO standards (i.e. total dissolved solids (TDS): in Al-Musaib, Al-Kufa, Al-Shamya station), and (calcium (Ca): in Al-Hindya Barrage station).
\end{abstract}

\section{Introduction}

Water resource form about $15 \%$ from area of Iraq which found in different forms like rivers, lakes and streams etc. These resources are necessary to lasting and assurance belonging of human, domestic requirements and another uses like irrigation and industrial uses.

The monitoring and assessment of water quality is based, ultimately, upon the fundament physical, chemical and biological properties of water. However, water quality monitoring and assessment is a process of analysis, interpretation and communication of those properties within the wider context of human activity and use, and the conservation of the natural environment. It is not a fixed process, therefore, but is adapted in the light of

*Corresponding Author: Eng.alaa.husaeen@uobabylon.edu.iq local, national or international needs. The final aim is to provide information useful for management. Styles and strategies of management vary greatly, depending on institutions, resources and priorities.

Many researchers have been interested in studying the water quality parameters. These parameters are analyzed either by applying different statistical model or by qualities comparison with available standards.

$$
\text { Al-Masri and Ali [1], Wasfi [2] }
$$

evaluated some pollution concentrations such as total hardness, sulphates, alkalinity, chlorides, calcium and magnesium in Tigris River through Baghdad city. The result of the study indicates that concentrations of total hardness, sulphates and calcium exceed the Iraqi permissible limits of drinking water. 
They noticed that the time and site of sampling were of high importance in effecting the measured concentrations.

Al-Delaimy [3] performed a study on the effect of some environmental factors and their correlation with the inlet of river in Baghdad city (7-Nissan water treatment plant), and at the outlet (Al-Rasheed water treatment plant). He predicated models to simulate the effect of these environmental factors (temperature, turbidity, $\mathrm{DO}, \mathrm{pH}$ and electrical conductivity) on the bacterial contents in river water by the adoption of single linear regression analysis test.

Al-Malikey [4] studied the determination of Tigris river water quality. $\mathrm{He}$ chose three stations for this purpose located at north, middle and south of Baghdad city. The result of the study shows that Tigris river water of good quality to be treated at north of Baghdad city.

Al-Husseini [5] evaluated some of water quality parameters of Shatt Al-Hilla river in four main water treatment plants abstracting their water from the sites situated along the river were selected as a case study. $\mathrm{He}$ found there is a noticeable increase in concentrations of chloride and sulphate especially at Al-Hsien water treatment plant during the different periods of the year and there were clear effects of municipal wastes of Al-Hilla city on levels of turbidity and bacteria.

Al-Fatlawi [6] studied some physical and chemical parameters in addition the qualitative and quantitative study for phytoplankton. Four trace elements were determined $(\mathrm{Fe}, \mathrm{Zn}, \mathrm{Cu}, \mathrm{Pb})$ in five stations which distributed along the Euphrates river from Al-Hindya reservoir to Al- Kifil town in the middle of Iraq. The results showed that the concentration of $\mathrm{NO}_{3}(1.56-360.62), \mathrm{NO}_{2}$ (0.38 -0.84), $\mathrm{SiO}_{2}(85.15-597.71), \mathrm{PO}_{4}$ (N.D. - 0.73 ) $\mu \mathrm{g} / \mathrm{l}$, the dissolved ( $\mathrm{Fe}, \mathrm{Zn}, \mathrm{Cu}, \mathrm{Pb}$ ) $(0.1-404)$, (N.D. - 1.2) , (N.D. - 0.7),(N.D. $-1.2)$, (N.D. - 1) ppm respectively.

Kalel [7] made a study for alteration of the following concentration parameters, turbidity, electrical conductivity, total hardness, calcium, magnesium, chloride, alkalinity, total dissolved solids, suspension solids and $\mathrm{pH}$-value. These concentrations were compared to those of World Health Organization (WHO). For both branches the quality of water was checked, conducting hypothesis test at $95 \%$ level of confidence for where T-distribution had been used. It has been found that water quality for both branches did not exhibit any difference.

Fahd [8] studied some of physical and chemical characteristics of Al-Masab Al-Aam river. Results show monthly variation in air temperature ranged $14-43 \circ \mathrm{C}$ and the light penetration was $38-64 \mathrm{~cm}$. Dissolved oxygen concentrations and free $\mathrm{CO}_{2}$ inversely correlated with water temperature. The total alkalinity of water was due to the bicarbonate and carbonate. Salinity between $4.20-8.40$ $\mathrm{g} / \mathrm{L}$. Significant positive relation were found between water temperature, alkalinity and salinity, while negative relation between dissolved oxygen and temperature.

\section{Data processing}

To gauge the success of the program, data of water quality of the Euphrates river are being analyzed monthly, and the pollution levels are being determined. The program depend five sampling stations along the river including (Al-Musaib, Al-Hindya Barrage, AlKufa, Al-Shamya and Al-Shenafya) as shown in Fig. (1).

\subsection{The independent variables}

They are also named as explanatory variables or predictors. Each one of the five sampling stations have specified independent variables which are assumed to have a reliable impact on water quality assessment.

\subsection{The dependent variable}

In the present work, the total dissolved solids in Al-Musaib, Al-Kufa, Al-Shamya and AlShenafya stations, and calcium in Al-Hindya Barrage stations were assumed to be the dependent variable and it varied greatly.

Table (1) shows the independent and dependent variables for Euphrates river used in these stations. In this study, water samples were analyzed at Al-Musaib station for the period between 2005 to 2007, Al-Hindya Barrage station for the period between 2000 to 
2007, and period between 2005 to 2007 for AlKufa, Al-Shamya and Al-Shenafya stations, to construct the monitoring system along Euphrates river.

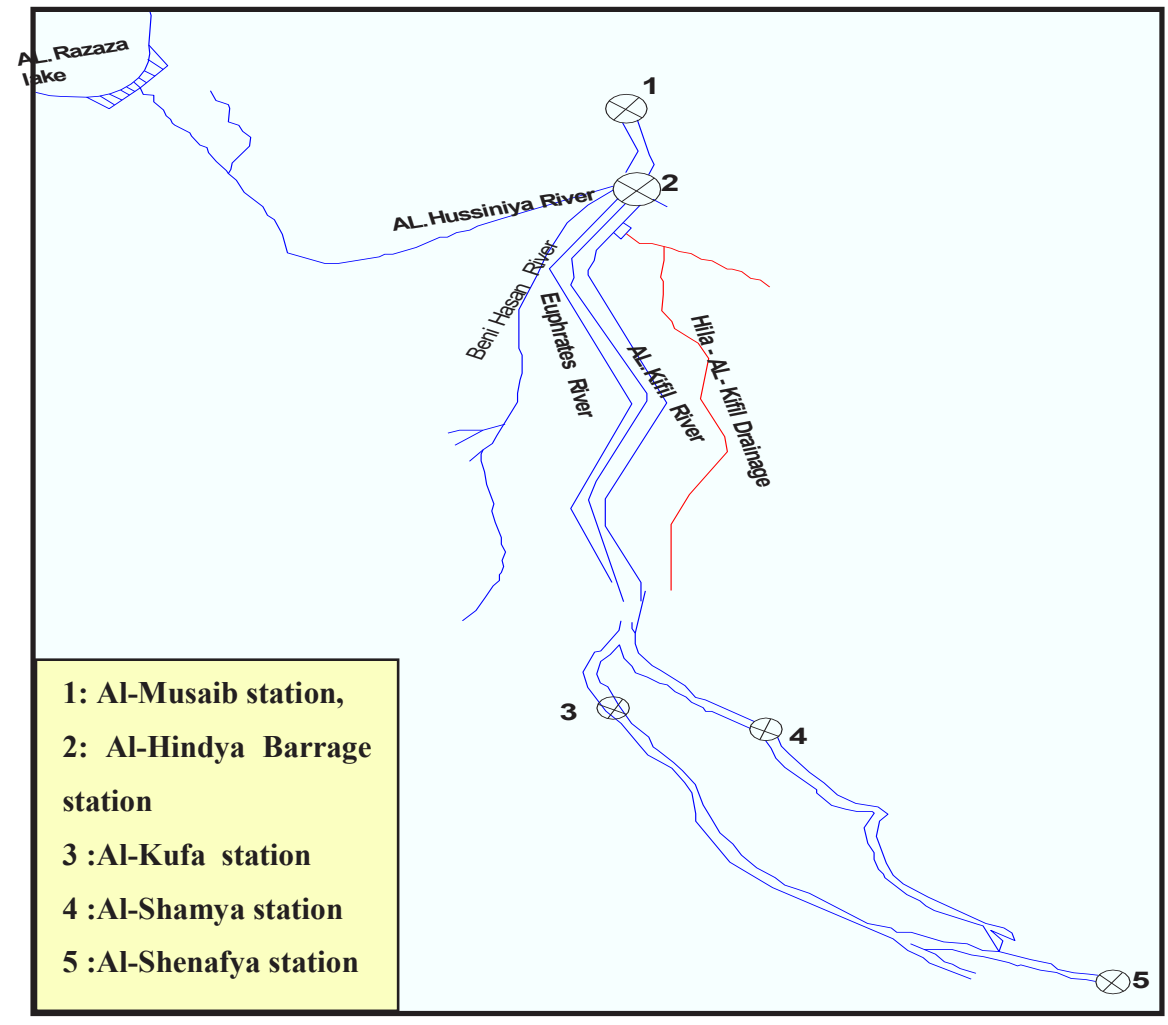

Fig. 1: Map of the studying area

Table 1: Description of independent and dependent variables of Euphrates river at different stations.

\begin{tabular}{|c|c|c|c|c|c|c|c|c|c|c|}
\hline \multirow{3}{*}{ Stations } & \multicolumn{10}{|c|}{ Variables } \\
\hline & \multicolumn{9}{|c|}{ Independent } & \multirow{2}{*}{$\frac{\text { Dependent }}{\mathrm{y}}$} \\
\hline & $\mathrm{x}_{1}$ & $\mathrm{x}_{2}$ & $\mathrm{x}_{3}$ & $\mathrm{X}_{4}$ & $\mathrm{X}_{5}$ & $\mathrm{x}_{6}$ & $\mathrm{x}_{7}$ & $\mathrm{X}_{8}$ & $\mathrm{X}_{9}$ & \\
\hline Al-Musaib & $\mathrm{pH}$ & Ec & $\mathrm{Ra}$ & $\mathrm{T}$ & - & - & - & - & - & TDS \\
\hline Al-Hindya Barrage & Ec & TDS & $\mathrm{So}_{4}$ & $\mathrm{TH}$ & $\mathrm{Mg}$ & $\mathrm{Cl}$ & $\mathrm{Ra}$ & Q & $\mathrm{T}$ & $\mathrm{Ca}$ \\
\hline Al-Kufa & $\mathrm{pH}$ & Ec & $\mathrm{Ra}$ & $\mathrm{T}$ & $\mathrm{RD}$ & SSD & $\mathrm{SD}$ & - & - & TDS \\
\hline Al-Shamya & $\mathrm{pH}$ & Ec & $\mathrm{Ra}$ & $\mathrm{T}$ & $\mathrm{RD}$ & SSD & SD & - & - & TDS \\
\hline Al-Shenafya & $\mathrm{pH}$ & Ec & $\mathrm{Ra}$ & $\mathrm{T}$ & $\mathrm{RD}$ & SSD & SD & - & - & TDS \\
\hline
\end{tabular}

Where: Ec : electrical conductivity $(\mu \mathrm{s} / \mathrm{cm})$,

TDS : total dissolved solids (mg/L),

$\mathrm{So}_{4}$ : sulphate $(\mathrm{mg} / \mathrm{L})$,

TH : total hardness $(\mathrm{mg} / \mathrm{L})$,

$\mathrm{Mg}$ : magnesium (mg/L),

$\mathrm{Cl}$ : chloride $(\mathrm{mg} / \mathrm{L})$,

$\mathrm{Q}$ : discharge $\left(\mathrm{m}^{3} / \mathrm{sec}\right)$,

$\mathrm{Ca}$ : calcium (mg/L),

$\mathrm{pH}$ : hydrogen ion concentration,

$\mathrm{Ra}$ : monthly rainfall totals $(\mathrm{mm})$, 
SSD : no. of days of suspended dust,

$\mathrm{RD}$ : no. of days of rising dust, SD : No. of days of storm dust, and

$\mathrm{T}$ : ambient temperature $\left({ }^{0} \mathrm{C}\right)$.

\section{Statistical analyses and regression models}

In standard regression analysis it is generally assumed that the determining (independent) variable is measured without error. All errors of measurement are then assigned to the determined (dependent) variable. The relationship between two normally distributed variables $\mathrm{x}$ and $\mathrm{y}$ can be expressed mathematically in a variety of ways.
In the present study, multiple nonlinear regression models in three forms were used for each design requirements to choose which form gives the best fitting of data. The regression models that were proposed and investigated can be seen in table (2).

Table 2: The proposed models.

\begin{tabular}{|c|l|}
\hline Rank & \multicolumn{1}{|c|}{ Equation Description } \\
\hline \hline $\mathbf{A}$ & $\mathrm{y}=\exp \left(\mathrm{b}_{1} \mathrm{x}_{1}+\mathrm{b}_{2} \mathrm{x}_{2}+\ldots+\mathrm{b}_{\mathrm{k}} \mathrm{x}_{\mathrm{k}}+\mathrm{G}\right)$ \\
\cline { 2 - 3 } & $\mathrm{y}=\mathrm{b}_{1} \mathrm{x}_{1}+\mathrm{b}_{2} \mathrm{x}_{2}+\ldots+\mathrm{b}_{\mathrm{k}} \mathrm{x}_{\mathrm{k}}+\mathrm{G}$ \\
\cline { 2 - 3 } & $\mathrm{y}=\mathrm{b}_{1} \mathrm{x}_{1}+\mathrm{b}_{2} \mathrm{x}_{2}+\ldots+\mathrm{b}_{\mathrm{k}} \mathrm{x}_{\mathrm{k}}$ \\
\hline
\end{tabular}

Where; $\mathrm{y}=$ dependent variables; $\mathrm{x}_{1}, \mathrm{x}_{2}, \ldots, \mathrm{x}_{\mathrm{k}}=$ the independent variables.

$b_{1}, b_{2}, b_{3}, \ldots, b_{k}=$ are model coefficients; and $G=$ model constant term.

Table (3), (4), (5), (6) and (7) show the correlation matrix in Al-Musaib, Al-Hindya Barrage, Al-Kufa, Al-Shamya and Al-
Shenafya station respectively. while plot models of these stations were shown in Figs. 2 to 6 .

Table 3: Correlation Matrix of Euphrates river in Al-Musaib station

\begin{tabular}{|c|c|c|c|c|c|}
\hline & $\mathbf{x} 1$ & $\mathbf{x}_{\mathbf{2}}$ & $\mathbf{x} 3$ & $\mathbf{x} 4$ & $\mathbf{y}$ \\
\hline $\mathbf{x}_{1}$ & 1 & -0.109 & 0.312 & -0.466 & -0.124 \\
\hline $\mathbf{x}_{2}$ & -0.109 & 1 & 0.323 & -0.280 & -0.389 \\
\hline $\mathbf{x}_{3}$ & 0.312 & 0.323 & 1 & -0.563 & -0.572 \\
\hline $\mathbf{x}_{4}$ & -0.466 & -0.280 & -0.563 & 1 & 0.931 \\
\hline $\mathbf{y}$ & -0.124 & -0.389 & -0.572 & 0.931 & 1 \\
\hline
\end{tabular}

Table 4: Correlation matrix of Euphrates river in Al-Hindya Barrage station

\begin{tabular}{|l|c|c|c|c|c|c|c|c|c|c|}
\hline & $\mathrm{x}_{1}$ & $\mathrm{x}_{2}$ & $\mathrm{X}_{3}$ & $\mathrm{x}_{4}$ & $\mathrm{X}_{5}$ & $\mathrm{X}_{6}$ & $\mathrm{X}_{7}$ & $\mathrm{X}_{8}$ & $\mathrm{X}_{9}$ & $\mathbf{y}$ \\
\hline $\mathbf{x}_{1}$ & 1 & & & & & & & & & \\
\hline $\mathbf{x}_{2}$ & 0.825 & 1 & & & & & & & & \\
\hline $\mathbf{x}_{3}$ & 0.564 & 0.574 & 1 & & & & & & & \\
\hline $\mathbf{x}_{4}$ & 0.489 & 0.501 & 0.810 & 1 & & & & & & \\
\hline $\mathbf{x}_{5}$ & 0.256 & 0.306 & 0.571 & 0.544 & 1 & & & & & \\
\hline $\mathbf{x}_{6}$ & 0.603 & 0.617 & 0.810 & 0.748 & 0.432 & 1 & & & & \\
\hline $\mathbf{x}_{7}$ & 0.233 & 0.167 & 0.365 & 0.380 & 0.120 & 0.299 & 1 & & & \\
\hline $\mathbf{x}_{8}$ & -0.010 & -0.076 & -0.003 & -0.152 & -0.092 & -0.084 & 0.045 & 1 & & \\
\hline $\mathbf{x 9}$ & -0.135 & -0.082 & -0.257 & -0.188 & 0.013 & -0.228 & -0.541 & -0.085 & 1 & \\
\hline $\mathbf{y}$ & 0.565 & 0.640 & 0.841 & 0.897 & 0.423 & 0.907 & 0.390 & -0.170 & -0.241 & 1 \\
\hline
\end{tabular}


Table 5: Correlation Matrix of Euphrates river in Al-Kufa station.

\begin{tabular}{|c|c|c|c|c|c|c|c|c|c|}
\hline & $\mathbf{x}_{1}$ & $\mathbf{x}_{2}$ & $\mathbf{X}_{3}$ & $\mathbf{X}_{4}$ & $\mathbf{X}_{5}$ & $\mathbf{X}_{6}$ & $\mathbf{x}_{7}$ & $\mathbf{X 8}$ & $\mathbf{y}$ \\
\hline $\mathbf{x}_{1}$ & 1 & & & & & & & & \\
\hline $\mathbf{x} 2$ & -0.282 & 1 & & & & & & & \\
\hline $\mathbf{X 3}$ & -0.085 & -0.100 & 1 & & & & & & \\
\hline $\mathrm{X} 4$ & -0.151 & 0.188 & -0.395 & 1 & & & & & \\
\hline $\mathbf{x}_{5}$ & 0.023 & -0.186 & 0.660 & -0.594 & 1 & & & & \\
\hline $\mathbf{x}_{6}$ & -0.033 & -0.369 & 0.689 & -0.422 & 0.726 & 1 & & & \\
\hline $\mathbf{X}_{7}$ & 0.136 & -0.331 & 0.552 & -0.363 & 0.629 & 0.796 & 1 & & \\
\hline $\mathbf{x} 8$ & 0.120 & -0.194 & 0.101 & 0.141 & 0.044 & 0.195 & 0.456 & 1 & \\
\hline $\mathbf{y}$ & -0.182 & 0.637 & -0.143 & 0.569 & -0.252 & -0.579 & -0.454 & -0.333 & 1 \\
\hline
\end{tabular}

Table 6: Correlation Matrix of Euphrates river in Al-Shamya station.

\begin{tabular}{|c|c|c|c|c|c|c|c|c|}
\hline & $\mathbf{x}_{1}$ & $\mathbf{x}_{2}$ & $\mathbf{X}_{3}$ & $\mathbf{X}_{4}$ & $\mathbf{X}_{5}$ & $\mathrm{X}_{6}$ & $\mathbf{x}_{7}$ & $\mathbf{y}$ \\
\hline $\mathbf{x}_{1}$ & 1 & & & & & & & \\
\hline $\mathbf{X}_{2}$ & 0.168 & 1 & & & & & & \\
\hline $\mathbf{X}_{3}$ & -0.267 & -0.011 & 1 & & & & & \\
\hline $\mathbf{X} 4$ & 0.355 & -0.097 & -0.562 & 1 & & & & \\
\hline $\mathbf{X} 5$ & 0.089 & -0.263 & -0.324 & 0.625 & 1 & & & \\
\hline $\mathbf{X}_{6}$ & -0.109 & -0.268 & -0.224 & 0.482 & 0.809 & 1 & & \\
\hline $\mathbf{X}_{7}$ & -0.378 & -0.147 & 0.168 & 0.034 & 0.270 & 0.505 & 1 & \\
\hline $\mathbf{y}$ & 0.295 & 0.906 & -0.176 & 0.035 & -0.404 & -0.450 & -0.306 & 1 \\
\hline
\end{tabular}

Table 7: Correlation Matrix of Euphrates river in Al-Shenafya station.

\begin{tabular}{|l|c|c|c|c|c|c|c|c|}
\hline & $\mathbf{x}_{\mathbf{1}}$ & $\mathbf{x}_{\mathbf{2}}$ & $\mathbf{x}_{\mathbf{3}}$ & $\mathbf{x}_{\mathbf{4}}$ & $\mathbf{x}_{\mathbf{5}}$ & $\mathbf{x}_{\mathbf{6}}$ & $\mathbf{x}_{\mathbf{7}}$ & $\mathbf{y}$ \\
\hline $\mathbf{x}_{\mathbf{1}}$ & 1 & & & & & & & \\
\hline $\mathbf{x}_{\mathbf{2}}$ & 0.244 & 1 & & & & & & \\
\hline $\mathbf{x}_{\mathbf{3}}$ & -0.224 & 0.085 & 1 & & & & & \\
\hline $\mathbf{x}_{\mathbf{4}}$ & 0.465 & -0.123 & -0.562 & 1 & & & & \\
\hline $\mathbf{x}_{\mathbf{5}}$ & 0.352 & -0.056 & -0.324 & 0.625 & 1 & & & \\
\hline $\mathbf{x}_{\mathbf{6}}$ & 0.180 & -0.157 & -0.224 & 0.482 & 0.809 & 1 & & \\
\hline $\mathbf{x}_{\mathbf{7}}$ & -0.009 & -0.052 & 0.168 & 0.034 & 0.270 & 0.505 & 1 & \\
\hline $\mathbf{y}$ & 0.309 & 0.959 & -0.034 & -0.031 & 0.027 & -0.165 & -0.199 & 1 \\
\hline
\end{tabular}




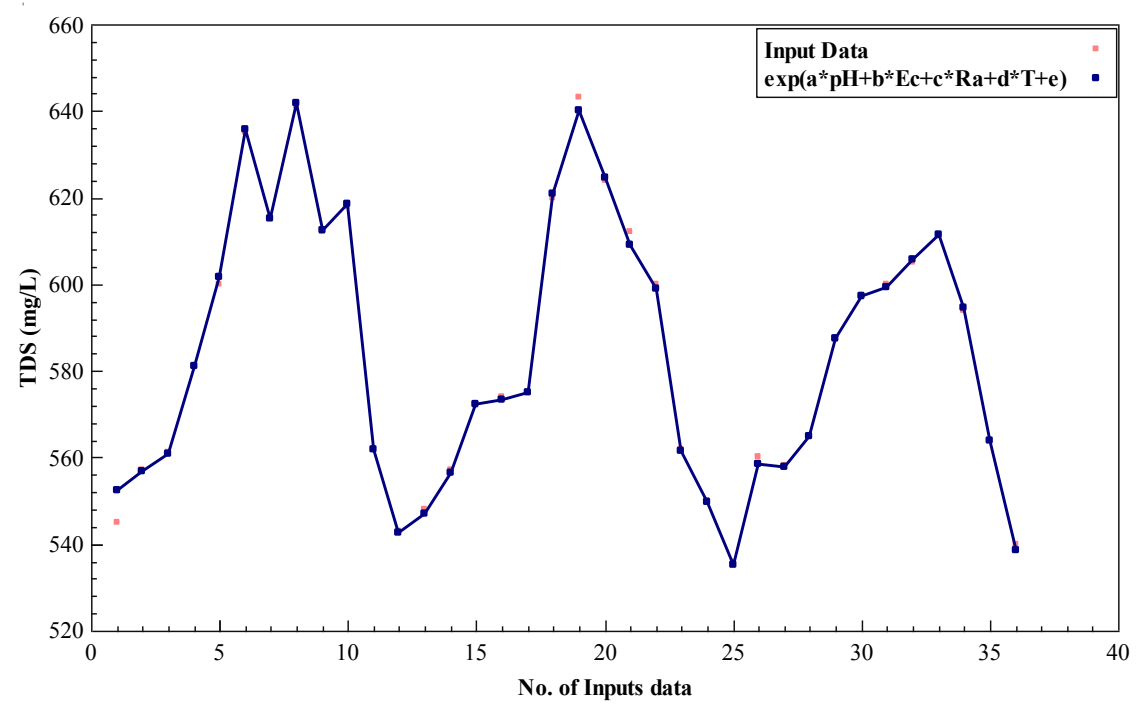

Fig. 2: Plot model of Euphrates river in Al-Musaib station

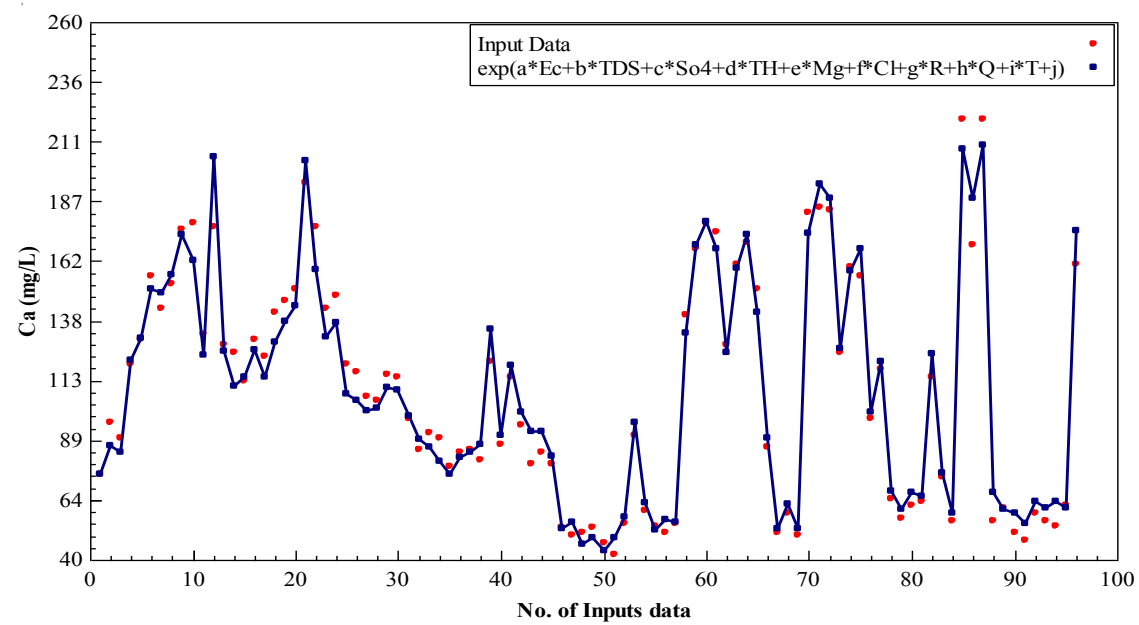

Fig. 3: Plot model of Euphrates river in Al-Hindya Barrage station.

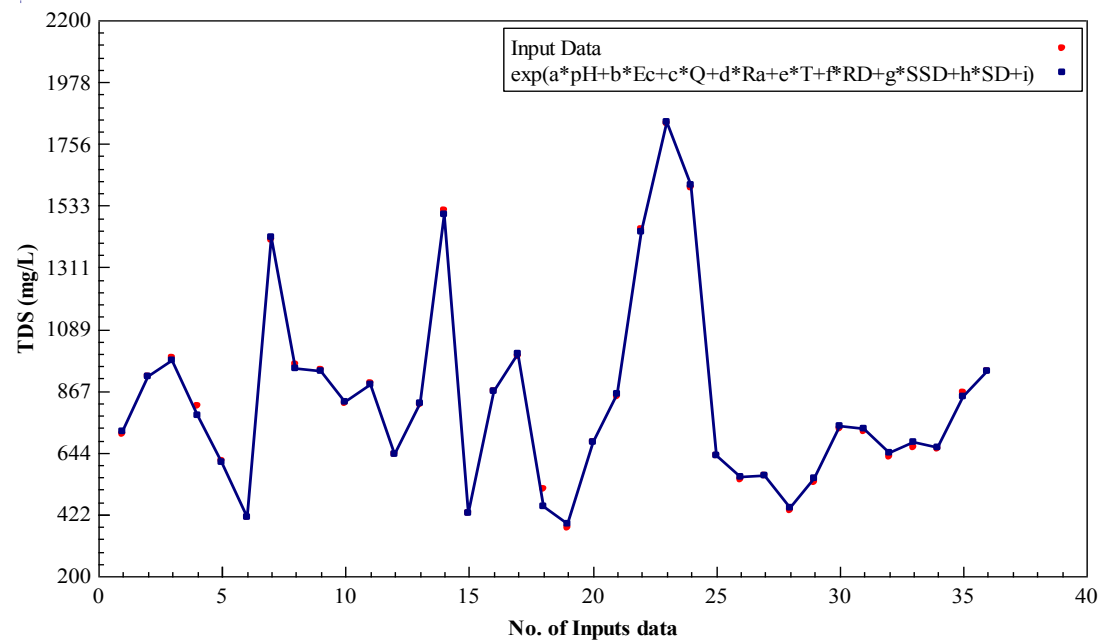

Fig. 4: Plot model of Euphrates river in Al-Kufa station 


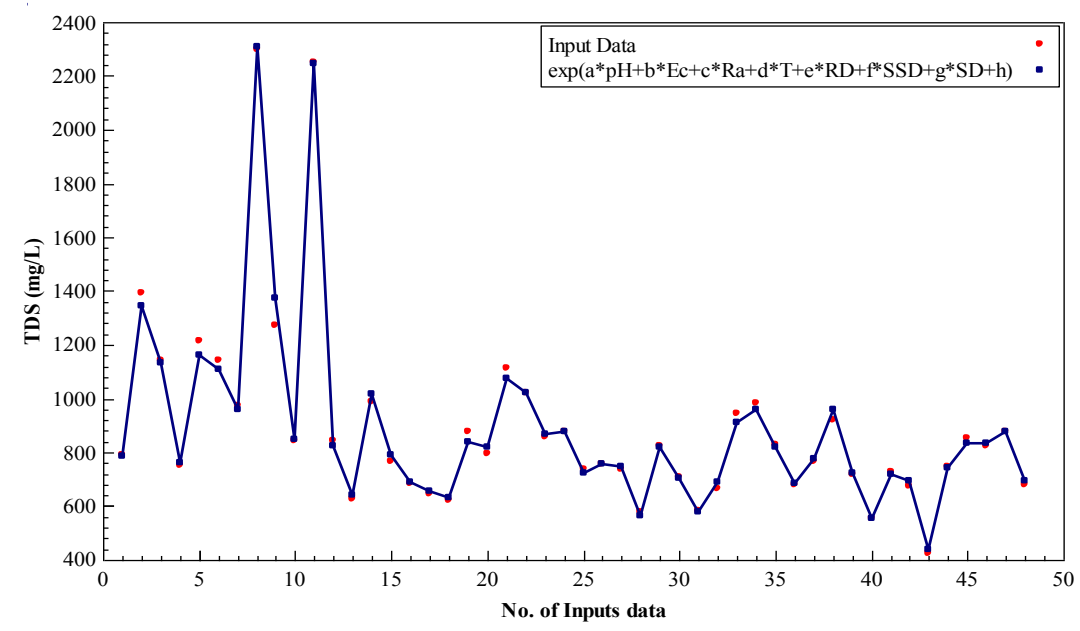

Fig. 5: Plot model of Euphrates river in Al-Shamya station

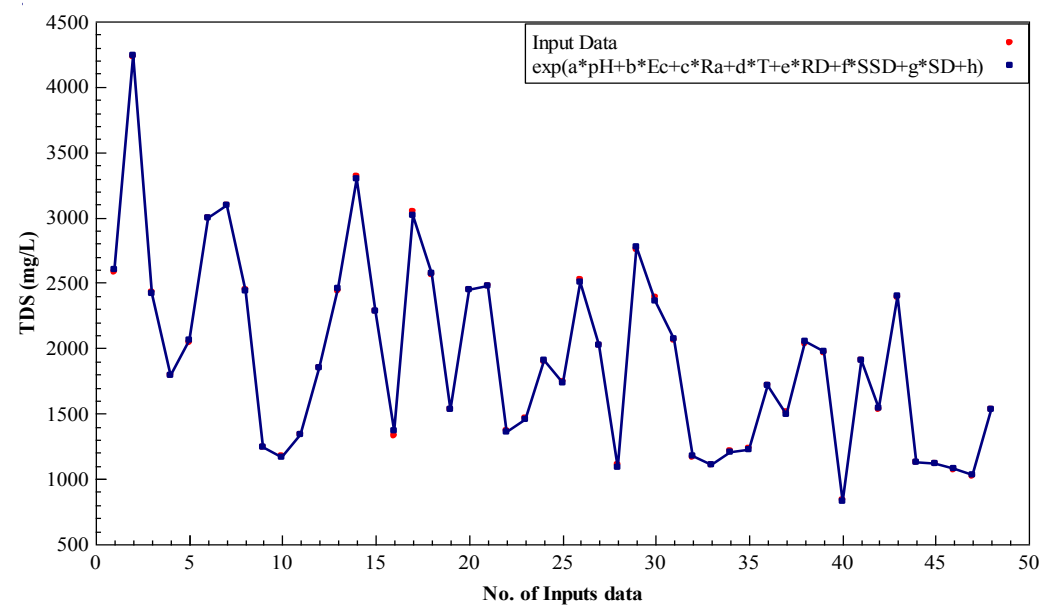

Fig. 6: Plot model of Euphrates river in Al-Shenafya station

\section{Verification of regression} model

Verification of the obtained model can be made by plotting the data of the year 2008 which were not included in the building of the regression model versus modeling data. The obtained model was also calibrated by the following equation:

$$
y=a x^{b}
$$

Verification of regression model is shown in Figs. (7 to 11). These Figs. showed that the experimental data are correlated well with modeling data. This verification shows a good agreement with coefficient of determination ranged between "0.914 to 0.994 ". 


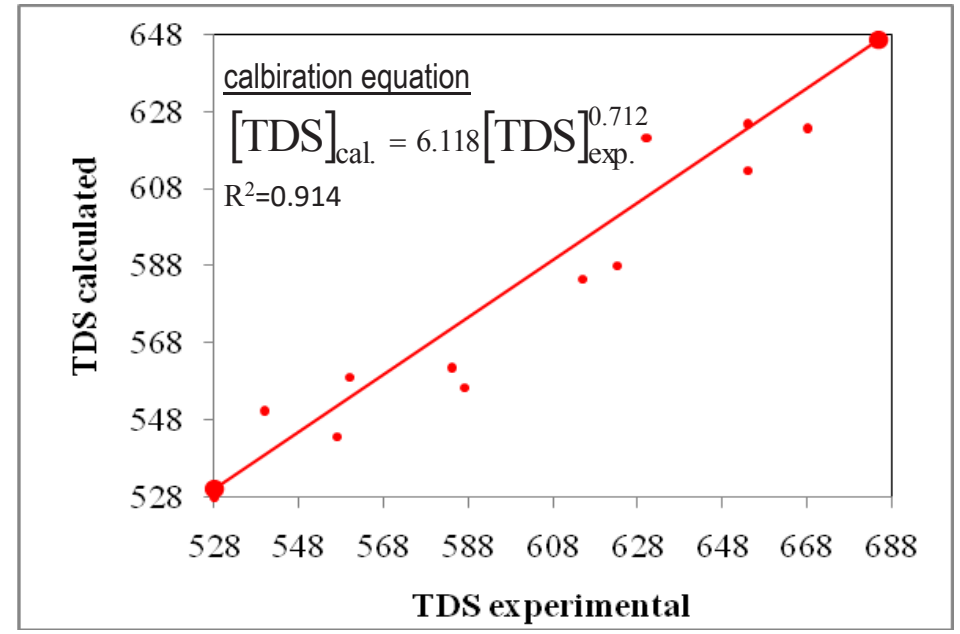

Fig.7: Verfication of regression model for Euphrates river in Al-Musaib station.

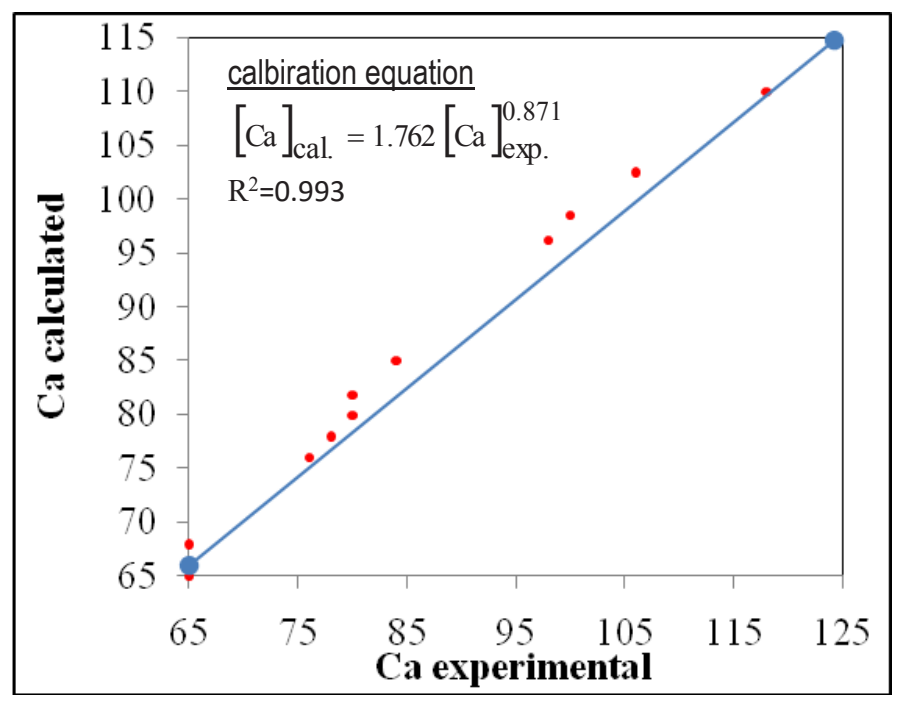

Fig. 8: Verfication of regression model for Euphrates river in Al-Hindya Barrage station.

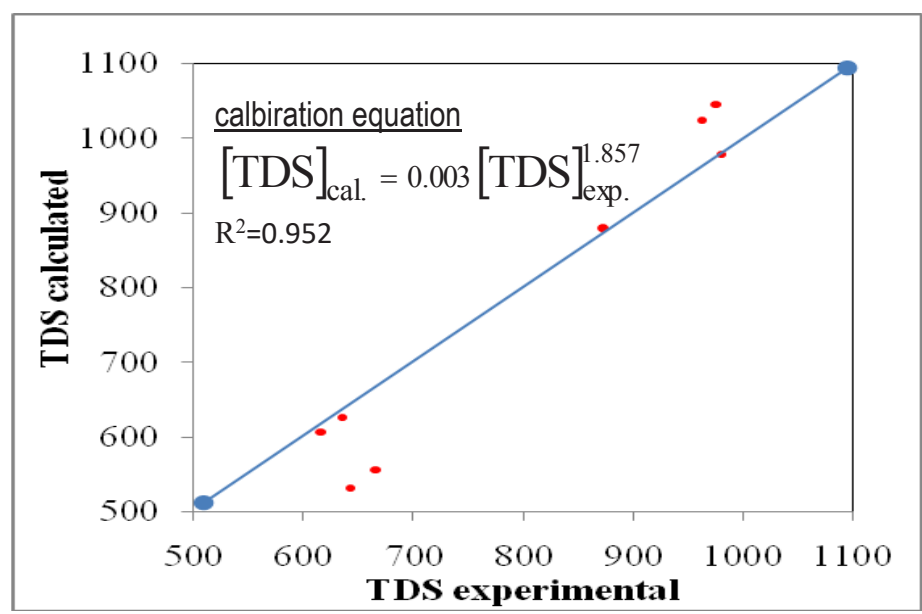

Fig. 9: Verfication of regression model for Euphrates river in Al-Kufa station. 


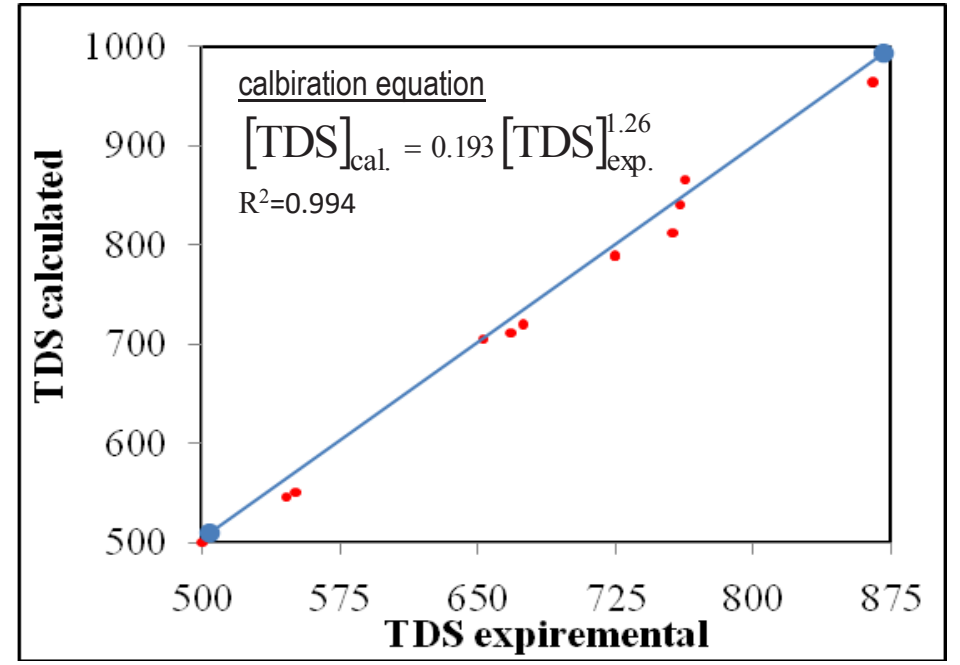

Fig.10: Verfication of regression model for Euphrates river in Al-Shamya station.

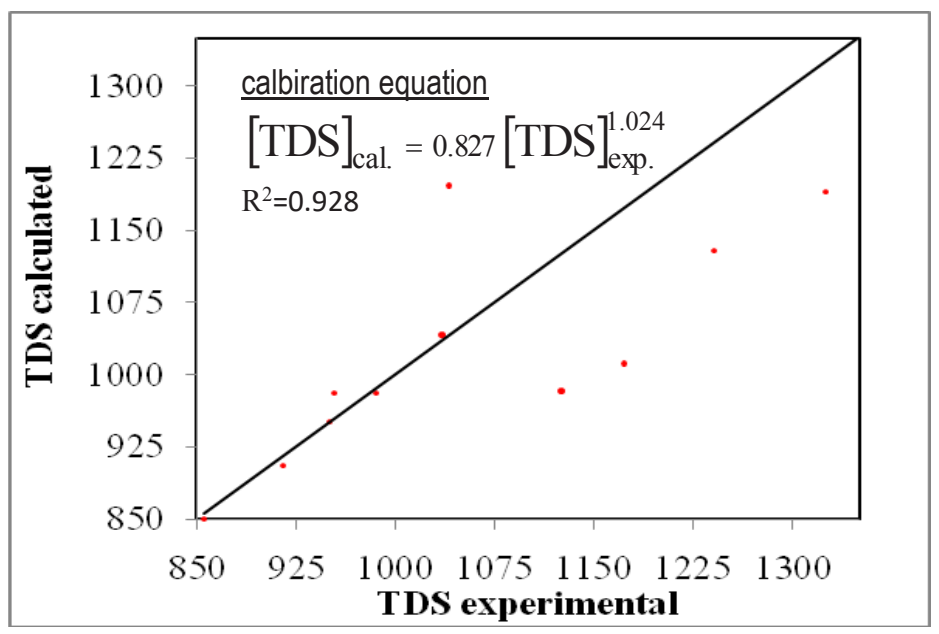

Fig. 11: Verfication of regression model for Euphrates river in Al-Shenafya station.

\section{Comparison of the program output data}

A Comparison of the program output data (TDS, Ca) are compared with the Iraqi and WHO standards for domestic and irrigation purposes (table 8). A Comparison shows that these parameters in some stations are within the Iraqi and WHO standards for domestic and irrigation purposes (table 9) (i.e. TDS: in Al-Musaib, Al-Kufa, AlShamya station), and (Ca: in Al-Hindya Barrage station). 
Table 8: Allowable limits of water quality parameters in surface water body used as domestic and irrigation water source according to Iraqi and WHO standards [9],[10]

\begin{tabular}{|l|c|c|c|l||}
\hline \multirow{2}{*}{ Parameter } & \multirow{2}{*}{ Unit } & \multicolumn{2}{|c|}{ Domestic water standards } & \multicolumn{1}{c|}{ Irrigation water standards } \\
\cline { 3 - 5 } & & Iraqi & WHO & \multicolumn{1}{c|}{ WHO } \\
\hline \hline pH & & $6.5-8.5$ & $6.5-8$ & $6-8.5$ \\
\hline Ec & $\mu \mathrm{s} / \mathrm{cm}$ & 2000 & - & $\begin{array}{l}<250 \text { Excellent, 250-750 Good and } \\
750-2000 \text { Permissible }\end{array}$ \\
\hline Ca & $\mathrm{mg} / \mathrm{L}$ & 200 & $75-200$ & $0-200$ \\
\hline Cl & $\mathrm{mg} / \mathrm{L}$ & 200 & $250-600$ & $0-300$ \\
\hline Mg & $\mathrm{mg} / \mathrm{L}$ & 50 & $30-150$ & $0-50$ \\
\hline TA & $\mathrm{mg} / \mathrm{L}$ & 170 & $5-200$ & - \\
\hline TDS & $\mathrm{mg} / \mathrm{L}$ & 1500 & $500-1000$ & $0-700$ Excellent, 700-2000 Good and \\
\hline TH & $\mathrm{mg} / \mathrm{L}$ & 500 & $100-500$ & \\
\hline Tur & $\mathrm{NTU}$ & $<10$ & $5-25$ & \\
\hline So4 & $\mathrm{mg} / \mathrm{L}$ & 200 & $200-400$ & \\
\hline
\end{tabular}

Table 9: Qualitative properties of Euphrates river for drinking and irrigation purposes.

\begin{tabular}{|l|c|c|c|}
\hline \multirow{2}{*}{ Station } & \multicolumn{3}{|c|}{ Raw water suitability for following purposes } \\
\cline { 2 - 4 } & \multicolumn{2}{|c|}{ Demotic } & Irrigation \\
\cline { 2 - 4 } & Iraqi & WHO & WHO \\
\hline Al-Musaib & Suitable & Suitable & Excelent \\
\hline Al-Hindya Barrage & Suitable & Suitable & Suitable \\
\hline Al-Kufa & Suitable & Suitable & Good \\
\hline Al-Shamya & Suitable & Suitable & Good \\
\hline Al-Shenafya & Suitable & Suitable & Good \\
\hline
\end{tabular}

\section{Description of computer program}

A computer program in a Visual Basic (software 6.0) was designed to construct a monitoring system that works with the data gathered to calculate the pollutant concentrations for river water and compare with the Iraqi and WHO standards for domestic and irrigation purposes.

The program was divided into three main parts: first named gathering of general information, second: calculation of the pollutant concentrations and third: data updating. The outputs data from statistical program (Data Fit version 8.0) were entered to the monitoring system designed as follow and shown in Figs. 12 to 18:

\subsection{Part 1: Gathering of the general information}

In this part, general information about the selected surface water is shown in the monitor forms. The user can select the water resource according to:

\footnotetext{
1. The type of surface water.

2. The name of surface water.

3. The station according to location of surface water.
}

\subsection{Part 2: Calculation of the pollutant concentrations}

This part of program calculates the concentrations of pollutant which polluted the surface water, then compared these concentrations with Iraqi and WHO for domestic and Irrigation purposes. The 
calculation depends on the database information about the surface water. The following steps were applying on Euphrates river in Al-Hindya Barrage station:

1. From the front page of the program in Fig. (12) click (Assessment Surface Water in the Middle Euphrates Region) button.

2. From the Combo Box in Fig. (13) select surface water type.

3. From Comb Box in Fig. (14) select the station of the surface water which selected in step (2).

4. From Fig. (15) select the regression model rank $\mathrm{A}, \mathrm{B}$ or $\mathrm{C}$.

5. Click the (Calculation) button in Fig. (16).
6 .

7 (17).

Click the (Comparison) button in Fig.

Fig. (18) gives the final result which can be used by decision makers.

\subsection{Part 3: Data updating}

Data updating is permitted for all information in the database. Updating includes:

1.Adding.

A. New water resource and corresponding information.

B. New station and corresponding information.

2.Updating of the existing data.

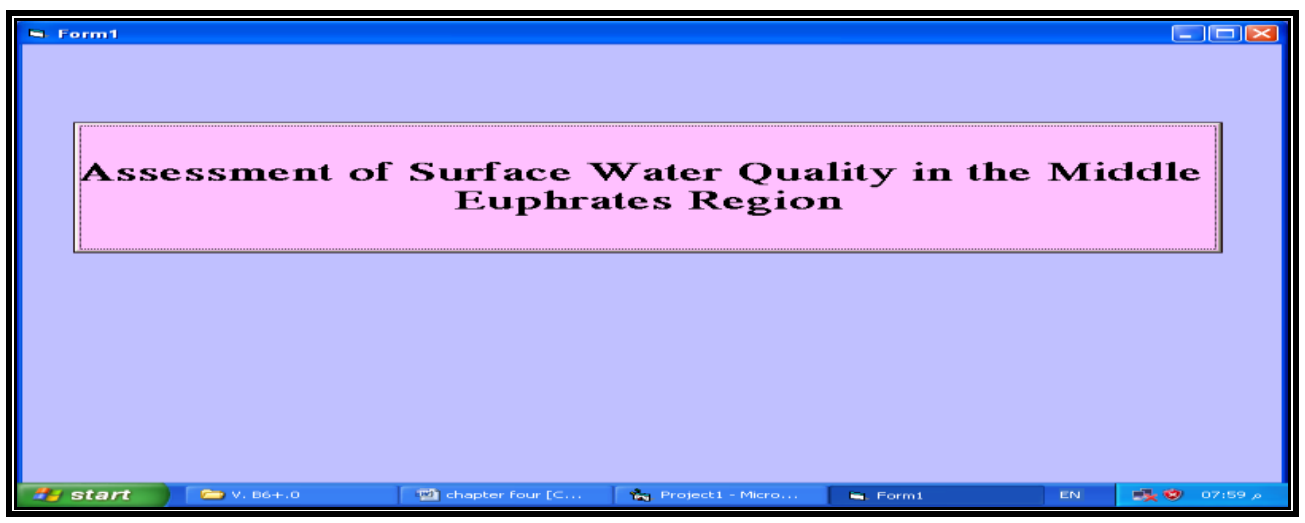

Fig. 12: Front page of program.

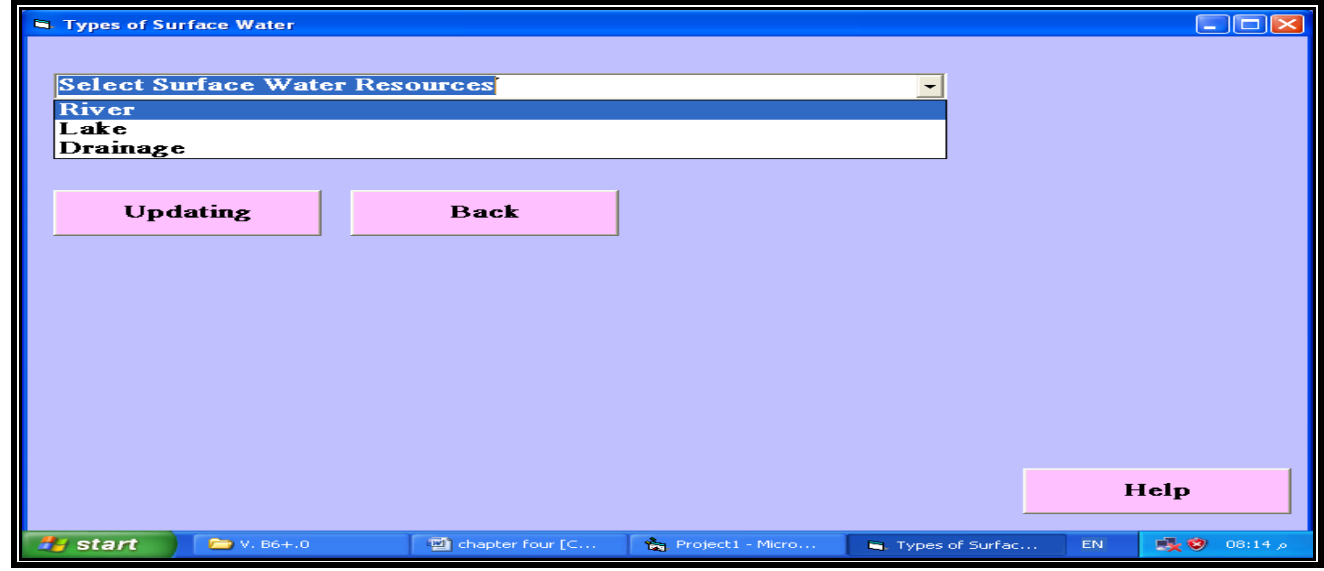

Fig. 13: Page to select the type of surface water. 


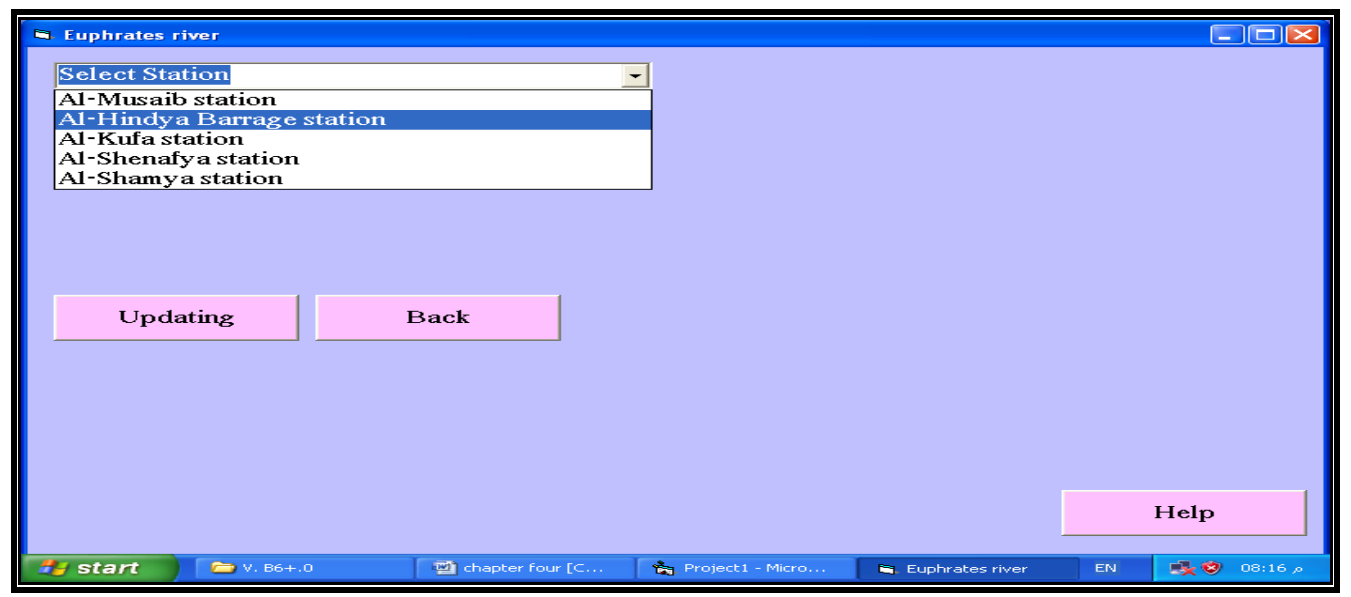

Fig. 14: Page of inputs data of Euphrates river in Al-Hindya Barrage station.

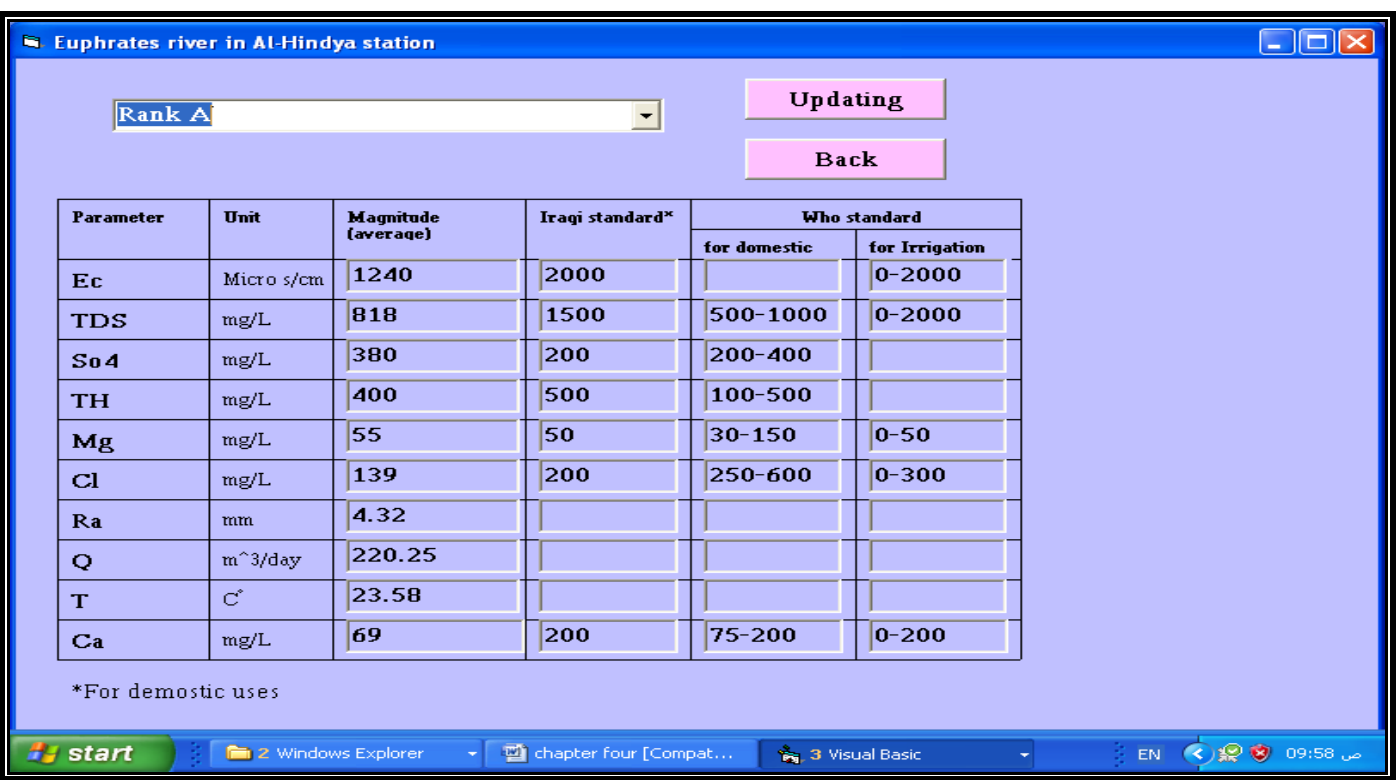

Fig. 15: Page of inputs data of Euphrates river in Al-Hindya Barrage station.

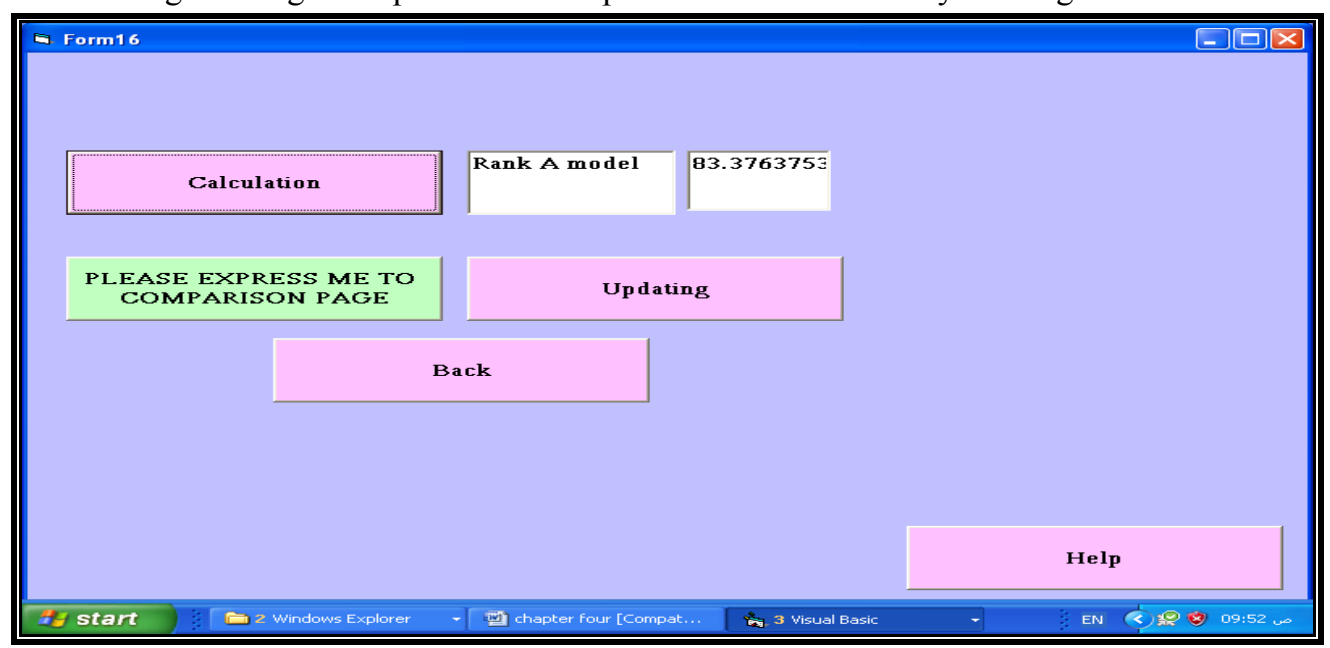

Fig. 16: Page of output data of Euphrates river in Al-Hindya Barrage station. 


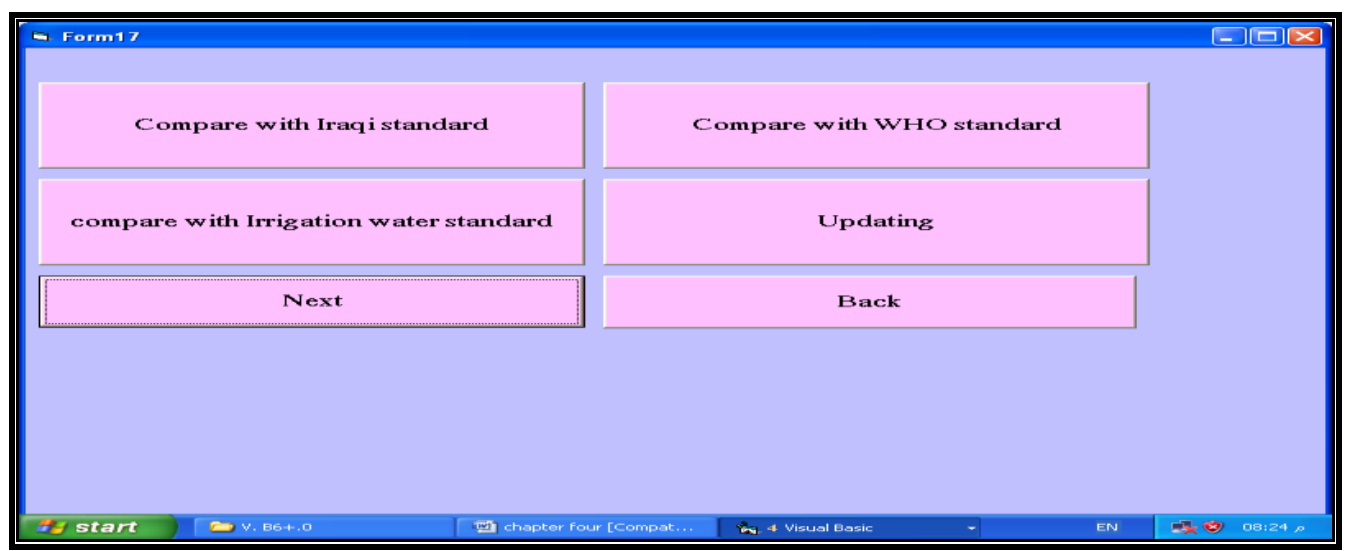

Fig. 17: Page of the comparison of Euphrates river in Al-Hindya Barrage station.

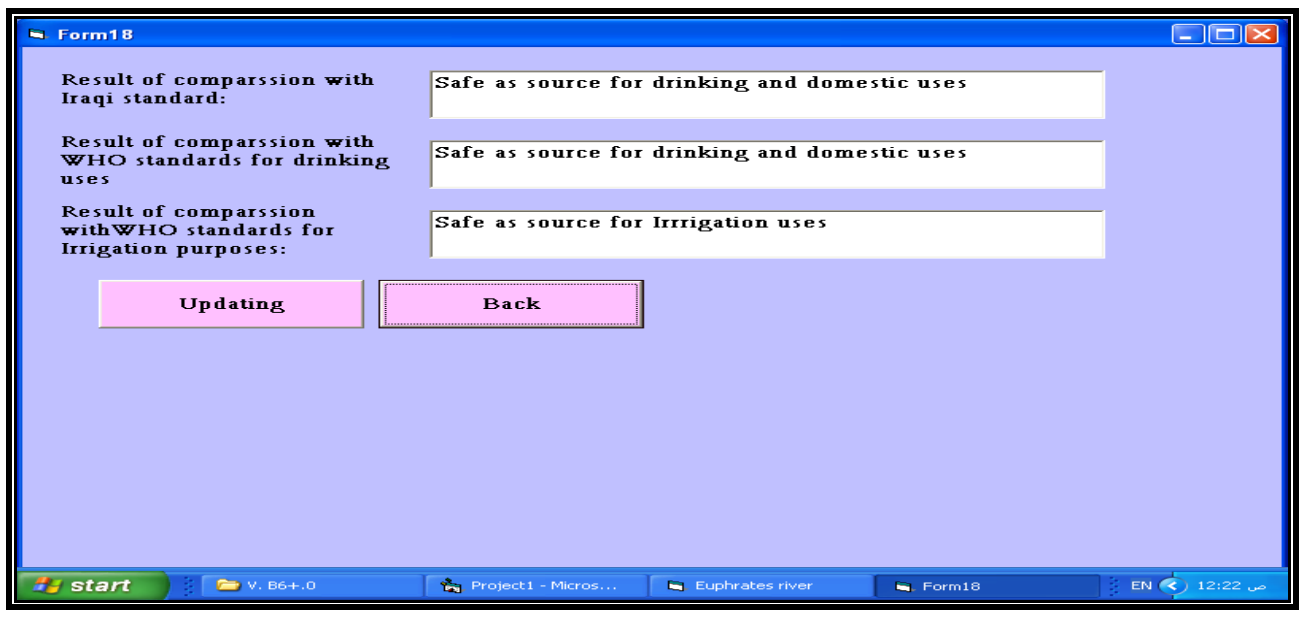

Fig. 18: Page of comparison of Euphrates river in Al-Hindya Barrage station.

\section{Conclusions}

From this study the following conclusions are obtained:

1. Environmental Assessment procedure is necessary to further characterize water quality condition of Euphrates river in the middle of Iraq.

2. Environmental Assessment approaches and techniques have much to offer in improving performance in water resources management and planning given the significant, and widely divergent, demands put on water resources.

3. The multiple regressions are found more suitable to evaluate the pollutants concentration.

4. Improved surface water quality in the middle of Iraq leading to improve the drinking water quality, reduced chemical treatment, reduce the rate of disease and improved hygienic conditions in the area.

5. For Euphrates river positive relation was found between total dissolved solids and temperature, while negative relation between total dissolved solids, hydrogen ion concentration, electrical conductivity and monthly rainfall totals in Al- Musaib station, also positive relation was found between total dissolved solids, electrical conductivity and monthly rainfall totals, while negative relation between total dissolved solids, hydrogen ion concentration, discharge, temperature, no. of days of rising, storm and suspended dust in $\mathrm{Al}$ Kufa station.

6. The verification models show a good agreement with coefficient of determination ranged between " 0.914 to 0.994 ". 
7. The computer program can be considered as a guide to the application of rapid technique in the inventory stage in each tool of the environmental management.

8. A Comparison of the program output data (TDS, Ca) shows that these parameters in some stations are within the Iraqi and WHO

\section{References}

1. Al-Masri, N., and Ali, A. A., 1985, "Effect of Domestic and Industrial Waste Water Discharge on Pollutant Variation in River Tigris", Proc. Of Iraqi conference on Engineering, ICE, 467-474, sited in AlHusseini.

2. Wasfi, A. A., 1986, "Evaluation of Tigris River Water Quality of Different Uses ", M. Sc. Thesis, University of Mosul

3. Al-Delaimy, H. H., 1989, "Effect of Tigris River Pollution on the Operation of AlRasheed Water Treatment Plant", M. Sc. Thesis, College of Engineering, University of Baghdad, sited in Al-Husseini.

4. Al-Malikey, S. J. B., 1993, "Effect of Tigris River Pollution on the Performance of Water Treatment Plants in Baghdad City", M. Sc. Thesis, College of Engineering, University of Baghdad, sited in AlHusseini.

5. Al-Husseini, H. H., 1999, "Evaluation of Shatt Al-Hilla Water quality for Domestic Use and the Suitability of Main Water treatment Plants on it", M. Sc. Thesis, College of Engineering, University of Babylon, sited in Al-Husseini

6. Al-Fatlawi, H. J., 2005, "Ecological Study for Euphrates River between Al-Hindya Reservoir and Al-Kifil Town/ Iraq ", M. SC. Thesis, College of Science, University of Babylon, In Arabic

7. Kalel, B., 2005, "Comparative Study in Water Quality of Euphrates between Shatt Al-Kufa and Shatt -Al-Abasiya ", Journal of Babylon University, Engineering Science, 10 (5): 1011-1021.

8. Fahd, K. K., 2006, "Some of PhysicoChemical Characteristics of Al-Masab AlAam River at Al-Nasiriyia City", Journal of Engineering Science, 10 (5): 1011-1021

9. Abbawi, S., A. and Mohsen M., S., 1990, "Environmental Practical Engineering-Water Testing", Muosel University, In Arabic. standards for domestic and irrigation purposes (i.e. TDS: in Al-Musaib, Al-Kufa, Al-Shamya station), and (Ca: in Al-Hindya Barrage station).

10. WHO, 2006," Guidelines for Drinking Water Quality", First Addendum to Third Edition, WHO Library Cataloguing, Publication Data, ISBN 924154696 4, Vol. 1, Recommendations, Third Edition, Geneva. 